\title{
AOR
}

Selected Papers of \#AoIR2018:

The $19^{\text {th }}$ Annual Conference of the

Association of Internet Researchers

Montréal, Canada / 10-13 October 2018

\section{EXPLORING THE RURAL DIGITAL LANDSCAPE: LIBRARIES, EQUITY, AND SCALE}

\author{
Dr. Sharon Strover \\ University of Texas at Austin \\ Dr. Alexis Schrubbe \\ University of Texas at Austin
}

\section{Background to the Problem}

Public libraries in large cities across the United States have been loaning out Hotspot devices as part of their regular catalog offerings for several years. Chicago,

Minneapolis, Seattle, Houston and Tulsa are just a few of these locations. These programs are robust and popular in urban locations, but offering similar programs in rural locations presents unique challenges. Rural libraries often have small staff numbers, small budgets, and are located in places that have limited cellular service on which hotspots depend. Due to budget and staff limitations of small and rural libraries, some locations do not have regular business hours (Swan et al., 2013). Additionally, as Internet connectivity has become essential to conduct so many routine activities of daily life, its absence and unaffordability create penalties for rural populations.

Few rural libraries have explored the potential of cellular-based hotspots to connect patrons with the Internet long after the library hours are over. The importance of hotspots in rural areas grows due to the fact that rural areas have fewer options for Internet service: rural areas often face slower speeds and face gaps in wireline provider access, leaving rural residents with slow or no service. About $70 \%$ of rural libraries are the only sites with free Internet in their communities (Real, et al. 2014), and they provide a wide range of economically-oriented services (Mehra et al., 2017). As well, rural residents pay more for commercial service than urban residents, and often the service is lower quality than service available in urban areas (NTIA, 2016; FCC 2015). The populations of rural areas also tend to be both older and lower income, so affording costly Internet is another challenge.

\section{Research Questions and Methods}

Suggested Citation (APA): Strover, S., Schrubbe, A.. (2018, October 10-13 Exploring The Rural Digital Landscape: Libraries, Equity, And Scale. Paper presented at AoIR 2018: The 19th Annual Conference of the Association of Internet Researchers. Montréal, Canada: AolR. Retrieved from http://spir.aoir.org. 
Drawing on theories of digital inclusion (Bertot 2009; Whitacre, Strover and Gallardo (2015; Gangadharan and Byrum, 2012), critical development communication, and infrastructure policy (Walsham, 2012; Strover, 2014), this research investigates rural hotspot lending programs in order to examine questions of scale and organizational capacity in the 21st century Internet environment and how the matter of rural Internet connectivity reflects on the broader framing of equity in national and state policy. Important core concepts include digital literacy, public and private space, the affordances of mobile access, how digital inequalities operate in rural communities, and the institutional setting that influences rural Internet. The research results bear on policy initiatives at the federal level (such as universal service) and at the state level. Specific questions are:

1. How do a public institutions and spaces (the library) interact with private uses of the Internet (in the home and other private spaces) as seen through the lens of rural hotspot lending programs? Where do matters of scale figure organizationally and in terms of local or national policy?

2. How might library Hotspot lending programs influence access gaps and digital literacy in rural areas? What are the broader institutional and personal dimensions of connectivity that frame conceptions of rural information needs, uses and gaps?

3. What types of community economic or social impacts can be linked to librarybased Hotspot lending, or to libraries' roles with Internet services more generally?

We examined programs sponsored by State Libraries in Kansas (18 rural libraries all over the state) and Maine (6 in the northernmost county) that partnered with the New York Public Library to implement hotspot lending. The locations were homogeneous ethnically (predominantly Caucasian), mainly lower income, and often beset by economic problems. For example, Washington County ME has the highest unemployment rate in the state and has a lower average income and higher poverty rate than other state counties (Mainegeneral medical, 2016).

This research uses qualitative and quantitative methods to create a comprehensive understanding of the information ecosystems present in these rural communities. Individual interviews with 26 library staff, over 100 individual stakeholders and eleven in-person focus group meetings with patrons who accessed the Hotspot program as well as patrons who did not access the program but were library users provide data regarding local information needs, a framework to assess rural Internet access, and the Hotspot program itself.

\section{Findings}

Community stakeholders, librarians, and individuals all asserted the importance of the Internet, and they underscore that Internet resources are significant everywhere. Library users stressed that absent Internet connectivity, they know they are missing out on crucial information and connections. Stakeholders stressed the link between the Internet and economic viability and its utility to limit out-migration. Internet applications 
including first-responder networks and telemedicine arose in multiple locations as a foundational need for a robust community, as well as its importance for redressing the homework gap.

The rural communities echo the results of the hotspot program in New York, where people who checked out the Hotspots have reported that having consistent, affordable, home-based access affords them avenues to remain socially connected, find economic opportunities, save money and time, and to feel like they could remain as competitive. Digital dignity, or feeling "equal to" everyone else, became a recurring theme in focus groups. Users reported more confidence in their digital skills.

Patrons who checked out the hotspot used the Hotspot as if it were a regular wireline subscription service: they communicated with family and friends, helped their children complete homework, consumed entertainment and looked for job opportunities online. However, the program implementation in the two states differed, reflecting different organizational approaches to scaling support systems. The library experiences more broadly also raised questions regarding these public institutions' roles with and broader framing of the Internet alongside the contentions and content problems it raises.

Where the hotspots functioned well, they were greatly appreciated. However, they were at best a band-aid in the more vexing problem of easy and affordable broadband. Hotspots elicit important debates libraries' broader institutional setting and their role in local information circulation. The matter of scale - critical to any discussion of the rural region - is addressed.

\section{Conclusions and Implications}

Hotspot lending in rural libraries is shaped both by library implementation schemes and also the availability of middle-mile infrastructure supporting local connectivity. When a robust hotspot lending program exists in a small community, local efforts can make a measurable impact in the lives of rural residents. When connectivity is less robust, patrons feel left out from the benefits of connectivity. Libraries represent public, trusted spaces and the Internet access they offer (through hotspots, wifi, and internally) extend a public space ethos beyond the walls of the institution.

A dearth of competitive options for Internet service or prohibitively expensive service costs render hotspot programs a modest improvement for individuals and a gateway for additional literacy-related services from libraries. Our research details the many ways that Hotspots ameliorated poor Internet connectivity and affected the lives of community members. The implications of Hotspot lending suggest that even on a small scale, efforts to increase local connectivity have consequences for those who remain unconnected. Hotspot lending is a novel way that institutions respond creatively to access gaps and reinforces other local efforts engage the Internet socially, civically, and economically in rural areas. At the same time, problems with how states and the federal government think about the types and costs of connectivity currently available and the broader support structure that is required to best serve rural regions are highlighted by 
our findings. Hotspot programs reflect on the difficulties policymakers create in their limited conceptualization of rural circumstances.

\section{References}

Bertot, J., Jaeger, P., McClure, C., Wright, C., Jensen, E. (2009, November). Public libraries and the Internet 2008-2009: Issues, implications, and challenges. First Monday. Retrieved from http://firstmonday.org/ojs/index.php/fm/article/view/2700/2351. doi:http://dx.doi.org/10.5210/fm.v14i11.2700.

Federal Communications Commission (2015). 2015 Broadband Progress Report. Accessed at https://www.fcc.gov/reports-research/reports/broadband-progressreports/2015-broadband-progress-report.

Federal Communications Commission (2016). 2016 Broadband Progress Report. Accessed at https://www.fcc.gov/reports-research/reports/broadband-progressreports/2016-broadband-progress-report.

Gangadharan, S. and Byrum, G. (2012). Introduction: Defining and measuring meaningful broadband adoption. International Journal of Communication, 6, 26012608.

MaineGeneral Medical Center (2016). Maine Shared Health Needs Assessment \& Planning Process. Available at

http://www.maine.gov/dhhs/mecdc/phdata/SHNAPP/documents/county-reports/wholereports/Maine \%20Shared\%20CHNA\%20WASHINGTON\%20County\%20Report-2-2916.pdf.

Mehra, B., Bishop, B. W., \& Partee II, R. P. (2017). Small Business Perspectives on the Role of Rural Libraries in Economic Development. Library Quarterly, 87(1), 17-35. https://doi.org/10.1086/689312.

National Telecommunications and Information Administration (2016). The State of the urban/rural digital divide. Accessed at https://www.ntia.doc.gov/blog/2016/stateurbanrural-digital-divide.

Real, B., Bertot, J., Jaeger, P. (March 2014). Rural public libraries and digital inclusion; Issues and challenges. Information Technology and Libraries, 6-24. Accessed at https://doi.org/10.6017/ital.v33i1.5141.

Strover, S. (2014). The U.S. digital divide: A call for a new philosophy. Critical Studies in Media Communication. 31 (2), 114-122.

Swan, D., Grimes, J. Owens, T. (2013). The State of Small and Rural Libraries in the United States. Institute of Museum and Library Services.

Walsham, G. (2012). Are we making a better world with ICTs? Reflections on a future agenda for the IS field. Journal of Information Technology, 27 (2), 87-93. 
